\title{
Assessment of Immunostimulatory Characteristics of Achyranthes aspera Seeds and Leaves Supplemented Diets in Labeo rohita Fingerlings
}

\author{
Amarjeet Singh ${ }^{1}$, Rina Chakrabarti ${ }^{1}$, JaiGopal Sharma ${ }^{2, *}$ \\ ${ }^{1}$ University of Delhi, Department of Zoology, Aqua Research Lab, Delhi 110 007, India \\ ${ }^{2}$ Delhi Technological University, Department of Biotechnology, Bawana Road, Delhi 110 042, India.
}

\section{Article History}

Received 27 November 2019

Accepted 13 October 2020

First Online 14 October 2020

\section{Corresponding Author}

Tel.: +911127666496

E-mail: sharmajaigopal@yahoo.com

\section{Keywords}

Immunostimulant

Lysozyme

Hemagglutination

Lysozyme $C$ and $G$

TNF- $\alpha$

\begin{abstract}
The effect of dietary supplementation of leaves and seeds of Achyranthes aspera on rohu, Labeo rohita fingerlings was evaluated. Three experimental diets containing 0.25 (D1) and $0.5 \%$ (D2) leaves and $0.5 \%$ (D3) seeds of $A$. aspera and control diet (D4) without plant ingredients were formulated. After 45 days of feeding, rohu were immunized with $20 \%$ chicken RBC. Tissue and blood samples were collected on days7,14 and 21 after immunization. Dietary supplementation significantly $(P<0.05)$ increased the average weight and specific growth rate of rohu. Serum lysozyme, myeloperoxidase, hemagglutination titer and nitric oxide synthase activities were significantly $(P<0.05)$ higher in D3 compared to others. This group was followed by D2 and D1. Significantly $(P<0.05)$ lower lipid and protein oxidations were found in D3 compared to others. This group was followed by D2 and D1. In hepatopancreas, lysozyme C, lysozyme G, tumor necrosis factor- $\alpha$ (TNF- $\alpha$ ) and interleukin-1 $\beta$ (IL-16) expressions were up-regulated while interleukin-10 (IL-10) expression was downregulated. In anterior kidney, lysozyme C, lysozyme $\mathrm{G}$ and IL-10 expressions were upregulated while $T N F-\alpha$ and $I L-16$ expressions were down-regulated. The dietary inclusion of leaves and seeds of $A$. aspera enhanced the growth, improved immune system and reduced oxidative stress of rohu.
\end{abstract}

\section{Introduction}

The occurrence of infectious diseases is a major challenge to the aquaculture industry as it is affecting sustainable aquaculture. Use of chemotherapeutants to control the disease problem has several disadvantages. It causes environmental pollution (Hektoen, Berge, Hormazabal, \& Yndestad, 1995), helps in the development of antibiotic resistant bacteria (Huys et al., 2000) and has residual effect on fish (Jian \& Wu, 2003). Hence, alternative strategies should be adopted to enhance fish resistance against diseases (Defoirdt, Sorgeloos, \& Bossier, 2011). Applications of natural immunostimulants, probiotics, prebiotics etc. are gaining importance to control the fish diseases (Wang, Sun, Liu, \& Xue, 2016) as these are eco-friendly and improve the immune system of fish. The non-specific immune response acts as a first line of defense and represents a wide range of immune responses (Dalmo, Ingebrigtsen, \& Bøgwald, 1997). Spleen, anterior kidney and thymus are the main lymphoid organs of the fish. Fish has cellular as well as humoral immune responses. So, it is essential to improve the immune system of fish using natural immunostimulants as feed additives.

The member of the Amaranthaceae family, Achyranthes aspera L. is widely distributed in India and it has high medicinal value. Many studies show the compositions of different parts of the plant. The whole plant contains ecdysterone (Banerji, Chintalwar, Joshi, \& Chadha, 1971); D-glucuronic acid and its ester are present in seeds (Hariharan \& Rangaswami, 1970); the roots contain an important aliphatic acid $n$-hexacos-14- 
enoic acid (Sharma, Vasudeva, \& Ali, 2009); three triterpenoid glycosides, linolenic and oleic acids are also found in the seeds of $A$. aspera (Rashmi, Dayal, \& Nagatsu, 2007; Chakrabarti, Srivastava, Kundu, Khare, \& Banerjee, 2012). In methanolic extract of $A$. aspera leaves, carbohydrates, phenolic compounds, saponins, tannins, oils, fats, alkaloids, flavonoids etc. are found (Priya, Kumar, Karthik, \& Rao, 2012). The mobile phases of 11 amino acids have been isolated from the leaves (Shendkar et al., 2013).

Many studies have documented that dietary inclusion of seeds and roots extract of $A$. aspera enhanced the innate immune system of catla Catla catla, common carp Cyprinus carpio and rohu Labeo rohita (Rao, Romesh, Singh, \& Chakrabarti, 2004; Rao \& Chakrabarti, 2004; Rao \& Chakrabarti, 2005a, 2005b; Chakrabarti et al., 2012; Srivastava \& Chakrabarti, 2012); seeds show antigen clearance properties in common carp (Chakrabarti \& Rao, 2012). In UV-B irradiated rohu and catla larvae, dietary inclusion of $A$. aspera seeds has also modulated defense systems (Singh, Sharma, \& Chakrabarti, 2013a, 2013b; Sharma, Singh, \& Chakrabarti, 2015).

So far, impact of leaves of $A$. aspera in fish diet has not been studied. The mid-column feeder rohu Labeo rohita is a high valued carp and like other carps, disease problem is also reported in rohu. Therefore, an attempt has been made to assess the impact of the leaves and seeds enriched diets on the physiology of rohu; the impact on relative mRNA expressions of some immune related genes of rohu was also documented.

\section{Materials and Methods}

\section{Diet Formulation}

The leaves and seeds of $A$. aspera were harvested from the outdoor plant growing facility of Department of Zoology, University of Delhi. Leaves were collected; washed 3 times with tap water; 2 times with sterilized water and dried in sun light. The dried leaves were ground and passed through sieve $(300 \mu)$ to obtain fine crude powder. The ripen seeds were also collected, cleaned manually and ground for getting crude powder of seeds. The leaves were added at two concentrations: 2.5 (diet 1, D1) and $5.0 \mathrm{~g} / \mathrm{kg}$ diet (diet 2, D2). The seeds powder was added at a rate of $5 \mathrm{~g} / \mathrm{kg}$ diet (diet 3, D3). Control diet (diet 4, D4) was prepared without any supplementation (Table 1). In earlier study, the optimum dose of seeds was recommended as $0.5 \%$ in diet of fish (Chakrabarti \& Srivastava, 2012). Based on this study, the present dose of $0.5 \%$ seed was selected. Pelleted diets (1 $\mathrm{mm}$ diameter) were prepared using Twin-screw extruder and pellets were oven dried. The composition of all four diets (AOAC, 1990) was analyzed.

\section{Culture of Fish and Feeding Regime}

Rohu fingerlings were obtained from a fish farm and acclimated in concrete tanks for 15 days. Then fingerlings ( $2.031 \pm 0.481 \mathrm{~g}$ ) were randomly distributed among four different feeding regimes. Twelve aquaria (60 L each) were used for the study (three aquaria per treatment) and the density was $10 \mathrm{fish} /$ aquaria. Fish were fed twice daily (9.00 a.m. and 5.00 p.m.) at the rate of $3 \%$ of body weight. The uneaten feed and feces were daily siphoned out from individual aquarium and uneaten feed was oven dried and measured with weighing balance.

A digital multi-parameter system (HQ 40d, Hach, USA) attached with specific probes for measurement of temperature, $\mathrm{pH}$, dissolved oxygen, conductivity and nitrate- $\mathrm{N}$ was used to monitor water quality parameters. Ammonia- $\mathrm{N}$ was measured with ammonia$\mathrm{N}$ electrode attached with electrochemistry meter (Orion VERSA STAR, Thermo Scientific, USA). The

Table 1. Test and control diets and proximate composition of prepared diets

\begin{tabular}{|c|c|c|c|c|}
\hline \multirow[b]{2}{*}{ Ingredient (g/kg diet) } & \multicolumn{3}{|c|}{ Test diets } & \multirow[b]{2}{*}{$\begin{array}{c}\text { Control diet } \\
\text { (D4) }\end{array}$} \\
\hline & $\begin{array}{c}0.25 \% \text { Leaves } \\
\text { (D1) }\end{array}$ & $\begin{array}{l}0.5 \% \text { Leaves } \\
\text { (D2) }\end{array}$ & $\begin{array}{l}0.5 \% \text { Seeds } \\
\text { (D3) }\end{array}$ & \\
\hline Fishmeal & 651.6 & 651.6 & 651.6 & 651.6 \\
\hline Wheat flour & 331.9 & 329.4 & 329.4 & 334.4 \\
\hline Cod liver oil & 10.0 & 10.0 & 10.0 & 10.0 \\
\hline Vitamin and mineral complex & 4.0 & 4.0 & 4.0 & 4.0 \\
\hline Leaves powder & 2.5 & 5.00 & - & - \\
\hline Seeds powder & - & - & 5.0 & - \\
\hline \multicolumn{5}{|c|}{$\begin{array}{l}\text { Proximate composition (g/100 g on } \\
\text { dry matter basis) }\end{array}$} \\
\hline Moisture & 11.09 & 10.03 & 9.43 & 7.14 \\
\hline Crude protein & 37.05 & 36.98 & 37.02 & 36.96 \\
\hline Crude fat & 9.24 & 7.82 & 8.31 & 8.64 \\
\hline Total carbohydrates & 34.47 & 37.05 & 37.21 & 40.06 \\
\hline Ash & 8.15 & 8.12 & 8.03 & 7.20 \\
\hline Crude fibre & 6.8 & 6.5 & 4.4 & 4.1 \\
\hline Energy (kcal/100g) ${ }^{*}$ & 369.24 & 366.50 & 371.71 & 385.84 \\
\hline
\end{tabular}

${ }^{*}$ Calculated digestible energy (Halver, 1976)

$\mathrm{DE}(\mathrm{kcal} / 100 \mathrm{~g})=[(\mathrm{CP} \mathrm{g} / 100 \mathrm{~g} \times 4)+(\mathrm{CF} \mathrm{g} / 100 \mathrm{~g} \times 9)+(\mathrm{TC} / 100 \mathrm{~g} \times 4)]$ 
standard methods were followed for nitrite and phosphate estimations (APHA, 2012). The water temperature, $\mathrm{pH}$ and conductivity were $27.16^{\circ} \mathrm{C}$ (27$\left.30^{\circ} \mathrm{C}\right), 7.91(7.80-8.13)$ and $629 \mu \mathrm{S} / \mathrm{cm}$ (565-667 $\mu \mathrm{S} / \mathrm{cm})$, respectively throughout the experiment. The level of dissolved oxygen was $6.2 \mathrm{mg} / \mathrm{L}(6.0-6.5 \mathrm{mg} / \mathrm{L})$. The levels of ammonia- $\mathrm{N}$, nitrate- $\mathrm{N}$, nitrite- $\mathrm{N}$ and phosphate were $0.15 \mathrm{mg} / \mathrm{L}(0.08-0.27 \mathrm{mg} / \mathrm{L}), 1.25 \mathrm{mg} / \mathrm{L}$ (0.70-1.58 mg/L), $0.003 \mathrm{mg} / \mathrm{L}(0.001-0.008 \mathrm{mg} / \mathrm{L})$ and $0.15 \mathrm{mg} / \mathrm{L}(0.02-0.21 \mathrm{mg} / \mathrm{L})$ respectively, during the experimental period. The whole experiment was conducted following the guidelines of Animal Ethics Committee, Department of Zoology, University of Delhi (DU/ZOOL/IAEC-R/2015/08).

\section{Preparation of Chicken RBC (c-RBC)}

The chicken blood was collected in Alsever's solution (1:3) and stored at $4^{\circ} \mathrm{C}$ for $24 \mathrm{~h}$. Then the settled $\mathrm{C}-\mathrm{RBC}$ was washed thrice with phosphate buffer saline (1X PBS, pH 7.4). Then $20 \mathrm{~mL}$ of $\mathrm{c}-\mathrm{RBC}$ was mixed with $80 \mathrm{~mL}$ of $1 X$ PBS (pH 7.4) to make $100 \mathrm{~mL}$ of $20 \%(\mathrm{v} / \mathrm{v}) \mathrm{c}-$ RBC solution. This solution was used for the immunization of fish.

\section{Immunization of Fish and Sample Collection}

After 45 days of initial feeding, fish from four treatments were anaesthetized using MS 222 (Sigma, USA); chicken RBC (c-RBC) solution ( $20 \mu \mathrm{L} ; 20 \%$, v/v) was injected intraperitoneally using $26 \mathrm{G} \times 1 / 2$ syringe $(0.45 \times$ $13 \mathrm{~mm}$ ). Fish were observed for any abnormal signs after immunization.

Rohu were sampled after immunization in the following sequence: on day-7, day-14 and day-21. On each sampling day, i.e. on days-7, 14 and 21 , rohu ( 2 fish/ aquaria, $2 \times 3=6$ / treatment) were collected and anaesthetized with MS222. The weight of fish was measured individually; blood was collected through caudal vein puncture of each fish and kept at $4^{\circ} \mathrm{C}$ overnight for clotting. The sample was centrifuged and the serum was stored at $-20^{\circ} \mathrm{C}$ for various assays. The tissue samples (hepatopancreas and anterior kidney) were collected after the collection of blood; tissues were used for enzymatic assays and gene expression study.

\section{Growth Parameters}

The weight of fish was measured on days-7, 14 and 21 after immunization using electronic balance (Shimadzu, AUX220, Japan). Specific growth rate (SGR) and condition factor (CF) were calculated using following formulae:

$$
\begin{gathered}
\text { SGR } \%=[\ln (\text { final weight })-\ln (\text { initial weight })] \times \\
100 / \text { experimental period (in days) }
\end{gathered}
$$

$\mathrm{CF}=($ wet body weight $\times 100) /(\text { total length })^{3}$

\section{Immunological Assays}

The turbidimetric method was used for serum lysozyme assay (Siwicki, 1989). Briefly, in $10 \mu \mathrm{L}$ serum, solution of Micrococcus lysodeikticus (100 $\mu \mathrm{L})$ was added. The initial and final (after $60 \mathrm{~min}$ of incubation) absorbance were recorded at $450 \mathrm{~nm}$ in a Microplate reader (Synergy H1 Hybrid Reader, Biotek, USA). The enzyme activity was expressed as $\mathrm{mg} / \mathrm{mL}$. The standard was prepared with hen's egg lysozyme.

Myeloperoxidase activity was measured by mixing serum $(10 \mu \mathrm{L})$ and Hank's balanced salt solution $(90 \mu \mathrm{L})$ in a microplate (Quade \& Roth, 1997). Then $35 \mu \mathrm{L}$ of 3, 3',5,5'-tetramethyl benzidine hydrochloride and hydrogen peroxide (Genei, India) were added in each sample. After 2 min of incubation, $4 \mathrm{M} \mathrm{H}_{2} \mathrm{SO}_{4}(35 \mu \mathrm{L})$ was added to stop the reaction. The optical density was recorded at $450 \mathrm{~nm}$.

Hemagglutination assay was performed with serum to check antigen-specific antibody titer. The $2 \%$ c-RBC solution (V/V), used for hemagglutination assay was prepared with phosphate buffer saline $(\mathrm{pH} 7.4)$. The 96-well plate (round bottom) was used for serial dilution of $50 \mu \mathrm{L}$ serum with PBS (pH 7.4). The $50 \mu \mathrm{L}$ of $\mathrm{c}-\mathrm{RBC}$ solution (2\%) was mixed to each sample. The whole mixture was allowed to stay for $1 \mathrm{~h}$ at room temperature and then kept at $4^{\circ} \mathrm{C}$. The hemagglutination reaction was observed in 96-well microplate and the reciprocal of highest dilution reflects the antigen specific antibody titer.

Nitric oxide synthase (NOS) activity of tissues was determined (Lee et al., 2003). The tissue (hepatopancreas/anterior kidney) was homogenized with $1 \mathrm{~mL}$ phosphate buffer $(\mathrm{pH} 7.4)$ and then centrifuged at $10,000 \times g$ at $4{ }^{\circ} \mathrm{C}$ for $15 \mathrm{~min}$. The supernatant $(100 \mu \mathrm{L})$ was taken in a 96 -well microplate, mixed with Griess reagent $(100 \mu \mathrm{L})$. After $10 \mathrm{~min}$, the optical density was measured at $540 \mathrm{~nm}$ and enzyme activity was given as $\mu \mathrm{M} / \mathrm{mg}$ tissue.

\section{Oxidation of Tissue Lipid and Protein}

The oxidation of lipid and protein were assayed in both hepatopancreas and anterior kidney separately. The tissue ( $1 \mathrm{~g})$ was washed with $9 \mathrm{~mL}$ of chilled potassium chloride $(1.15 \%)$ and homogenized with 900 $\mu \mathrm{L}$ of chilled $1.15 \% \mathrm{KCl}$ for lipid peroxidation assay (Ohkawa, Ohishi, \& Yagi, 1979). Then $25 \mu \mathrm{L}$ homogenate was taken in $2 \mathrm{~mL}$ micro-centrifuge tube and mixed with $25 \mu \mathrm{L}$ of sodium dodecyl sulphate (8.1\%), $187.5 \mu \mathrm{L}$ of $20 \%$ acetic acid ( $\mathrm{pH} 3.5$ ) and $187.5 \mu \mathrm{L}$ of thiobarbituric acid $(0.8 \%)$. Then distilled water was added to make the total volume of reaction mixture $0.5 \mathrm{~mL}$; it was incubated for $1 \mathrm{~h}$ at $95^{\circ} \mathrm{C}$ in water bath. The sample was centrifuged for $15 \mathrm{~min}$ at $800 \times g$ at $4^{\circ} \mathrm{C}$. The absorbance of supernatant was measured at $532 \mathrm{~nm}$ and the concentration of thiobarbituric acid reactive substances was given as $\mu \mathrm{mol} \mathrm{MDA} / \mathrm{mg}$ tissue. 
Protein oxidation was measured in the form of carbonyl protein in tissues (Lenz, Costabel, Shaltiel, \& Levine, 1989). The tissue (100 mg) was homogenized with $1 \mathrm{~mL}$ of $50 \mathrm{mM}$ potassium phosphate buffer $(\mathrm{pH}$ 7.0) that contains Ethylene Diamine TetraAcetic Acid (0.5 mM) and phenyl methylsulfonyl fluoride (100 $\mu \mathrm{M})$. The homogenate $(250 \mu \mathrm{L})$ was mixed with $0.5 \mathrm{~mL}$ of trichloro acetic acid (10\%); then centrifuged at $13,000 \mathrm{x}$ $g$ for $5 \mathrm{~min}$. The pellet was mixed with $1 \mathrm{~mL}$ of $10 \mathrm{mM}$ dinitrophenyl hydrazine and kept at room temperature for $1 \mathrm{~h}$. Then centrifuged at 13,000 $\mathrm{xg}$ for $5 \mathrm{~min}$ and the pellet was washed thrice with $1 \mathrm{~mL}$ of ethanolbutylacetate $(1 / 1, v / v)$. The pellet was completely dissolved with $6 \mathrm{M}$ guanidine hydrochloride and again centrifuged. The absorbance of supernatant was recorded at $370 \mathrm{~nm}$. The activity was quantified as nanomoles/mg protein using $22 \times 10^{3} / \mathrm{M} / \mathrm{cm}$ molar extinction coefficient.

\section{Relative mRNA Expression Study}

The expressions of various immune related genes viz. lysozyme $\mathrm{C}$, lysozyme $\mathrm{G}$, tumor necrosis factor $\alpha$ (TNF- $\alpha$ ), interleukin $1 \beta$ (IL-1 $\beta$ ) and interleukin 10 (IL-10) were studied for both hepatopancreas and anterior kidney. The total RNA extraction was carried out in TRIzol $^{\mathrm{TM}}$ (Invitrogen ${ }^{\mathrm{TM}}$, USA) using the protocols provided by manufacturer. The RNA concentration was assayed with Nanodrop Spectrophotometer (ND-1000, Thermo Scientific, USA). The RNA samples with $260 / 280$ ratio of 2.0 was used for cDNA preparation. RNA ( $1 \mu \mathrm{g})$ was mixed with DNase I enzyme (Amplification grade, 1 $U$, Sigma- Aldrich, USA). It removed the genomic DNA contamination if present in the RNA. In 1\% agarose gel, the quality and purity of RNA was estimated. The cDNA Reverse Transcription kit (Applied Biosystems, USA) was used to reverse transcribe the RNA into CDNA as per manufacturer's protocol. The PCR amplification with $\beta$ actin primers and prepared CDNA template established the quality of cDNA synthesis.

The SYBR ${ }^{\text {TM }}$ Green Master Mix (Applied Biosystems) was used for relative mRNA quantification of different genes in Quant Studio 6 Flex machine (Applied Biosystems). The primer-BLAST, an online tool of NCBI-NIH was used for designing specific primers (Table 2). Each primer was run with serially diluted cDNA template. Then standard curve was prepared and melt curve was analyzed to check the efficiency of primers. The reaction mixture $(10 \mu \mathrm{L})$ consisted of $5 \mu \mathrm{L}$ of $2 \times$ SYBR $^{\mathrm{TM}}$ Green Master Mix, $0.25 \mu \mathrm{L}$ of each gene specific Forward primer as well as Reverse primer (Both 2.5 $\mu \mathrm{mol}$ ), $1 \mu \mathrm{L}$ cDNA template (dilution $1 / 3$ ) and $3.5 \mu \mathrm{L}$ of water (nuclease-free). The 40 cycles were run using software v1.1. The details of one cycle were as follows: pre-denaturation at $95^{\circ} \mathrm{C}$ for $10 \mathrm{~min}$, followed by denaturation at $95^{\circ} \mathrm{C}$ for $15 \mathrm{~s}$ and then annealing and extension at $60^{\circ} \mathrm{C}$ for $1 \mathrm{~min}$. The reaction specificity was evaluated using melt curve analysis. The details of melt curve plot were: $95^{\circ} \mathrm{C}-15 \mathrm{~s}, 60^{\circ} \mathrm{C}-1 \mathrm{~min}$ and $95^{\circ} \mathrm{C}-15 \mathrm{~s}$. The gene expression results were estimated using $2^{-\Delta \Delta C t}$ method (Livak \& Schmittgen, 2001) after verification of $100 \%$ primer amplification efficiency. Duplicate samples were run in 96-well plate (Applied Biosystems) with each target gene. The efficiency of reaction was also checked with duplicate non-template control. The house keeping

Table 2. Real-time PCR primer pairs for reference and target genes and their efficiency and slope values calculated in Quant Studio 6 Flex Real Time PCR system (Applied Biosystems, USA)

\begin{tabular}{|c|c|c|c|c|}
\hline Target gene & Primer sequence $\left(5^{\prime}-3^{\prime}\right)$ & Accession number/reference & Efficiency (\%) & Slope \\
\hline \multirow[t]{2}{*}{ Lysozyme C } & F- CGATGATGGCACTCCAGGT & EF203085.1 & 99.079 & -3.344 \\
\hline & R- CATGCTTTCAGTCCTTCGGC & & & \\
\hline \multirow[t]{2}{*}{ Lysozyme G } & F- CAATGGCTTTGGCCTCATGC & КС934746.1 & 95.477 & -3.435 \\
\hline & R- CACGTGGGAAACTTTGCTCTG & & & \\
\hline \multirow[t]{2}{*}{ TNF- $\alpha$} & F- GGCGGCTTGAAAGTAGTGGA & FN543477.1 & 97.660 & -3.379 \\
\hline & R-TATGCAGAACGTCGTGGTCC & & & \\
\hline \multirow[t]{2}{*}{ IL-1 $1 \beta$} & F- GTACCCCACAAAACATCGGC & AM932525.1 & 93.037 & -3.501 \\
\hline & R- CAAGAGCAGTTTGGGCAAGG & & & \\
\hline \multirow[t]{2}{*}{ IL-10 } & F- GCTCAGTGCAGAAGAGTCGAC & Banerjee, Mitra, Purohit, Mohanty, & 92.143 & -3.526 \\
\hline & R- CCCGCTTGAGATCCTGAAATATA & \& Mohanty, 2015 & & \\
\hline \multirow[t]{2}{*}{$\beta$-actin } & F- GACTTCGAGCAGGAGATGG & Mohanty \& Sahoo, 2010 & 94.160 & -3.470 \\
\hline & R- CAAGAAGGATGGCTGGAACA & & & \\
\hline
\end{tabular}

Table 3. Effect of $A$. aspera leaves and seeds enriched diets on the growth performances of rohu fingerlings. Means ( $\pm \mathrm{SE}$ ) sharing different letters in the same column are significantly $(P<0.05)$ different $(n=3)$

\begin{tabular}{|c|c|c|c|c|c|c|c|c|c|}
\hline & \multicolumn{3}{|c|}{ Final Weight (g) } & \multicolumn{3}{|c|}{ Specific Growth Rate (\%) } & \multicolumn{3}{|c|}{ Condition Factor (CF) } \\
\hline & 7 Days & 14 Days & 21 Days & 7 Days & 14 Days & 21 Days & 7 Days & 14 Days & 21 Days \\
\hline D1 & $5.30 \pm 0.13^{c}$ & $5.98 \pm 0.03^{c}$ & $6.57 \pm 0.09^{c}$ & $1.85 \pm 0.05^{c}$ & $1.78 \pm 0.01^{\mathrm{c}}$ & $1.80 \pm 0.02^{c}$ & $1.77 \pm 0.02^{c}$ & $1.80 \pm 0.01^{\mathrm{c}}$ & $1.83 \pm 0.02^{\mathrm{c}}$ \\
\hline D2 & $5.98 \pm 0.30^{b}$ & $6.88 \pm 0.05^{b}$ & $7.48 \pm 0.09^{b}$ & $2.08 \pm 0.10^{b}$ & $2.08 \pm 0.01^{b}$ & $1.99 \pm 0.02^{b}$ & $1.89 \pm 0.01^{b}$ & $1.86 \pm 0.02^{b}$ & $1.91 \pm 0.03^{b}$ \\
\hline D3 & $6.57 \pm 0.10^{\mathrm{a}}$ & $8.27 \pm 0.19^{a}$ & $9.23 \pm 0.02^{\mathrm{a}}$ & $2.27 \pm 0.03^{a}$ & $2.38 \pm 0.04^{a}$ & $2.29 \pm 0.01^{\mathrm{a}}$ & $1.94 \pm 0.01^{\mathrm{a}}$ & $1.92 \pm 0.01^{\mathrm{a}}$ & $1.97 \pm 0.01^{a}$ \\
\hline D4 & $4.32 \pm 0.05^{d}$ & $4.93 \pm 0.08^{d}$ & $5.50 \pm 0.12^{d}$ & $1.46 \pm 0.02^{\mathrm{d}}$ & $1.51 \pm 0.03^{d}$ & $1.52 \pm 0.03^{d}$ & $1.82 \pm 0.03^{c}$ & $1.81 \pm 0.02^{c}$ & $1.80 \pm 0.02^{c}$ \\
\hline
\end{tabular}

D1: $0.25 \%$ leaves, D2: $0.5 \%$ leaves, D3: $0.5 \%$ seeds and D4: control

The interactive effect of diets and sampling days is significant $(P<0.05)$ for final weight and non-significant $(P>0.05)$ for specific growth rate $(\%)$ and condition factor of rohu. 
gene $\beta$-actin was also run with the same cDNA template and used for normalization of samples.

\section{Statistical Analysis}

The results were presented as means \pm SE. The normality of the data was evaluated using Shapiro-Wilk test (1965). Data were analyzed using one-way analysis of variance with Duncan's multiple range test (Montgomery, 1984). The two-way analysis of variance was performed for growth parameters. The statistical software IBM SPSS version 24 was used for analysis. The significance was considered at $\mathrm{P}<0.05$ level.

\section{Results}

\section{Growth Performance}

There was no mortality of fish cultured in different treatments. Rohu fed with D3 diet showed significantly $(P<0.05)$ higher final weight and SGR\% compared to rohu fed with other diets on days-7, 14 and 21after immunization (Table 3). The final weight was lowest in diet D4 fed rohu. The final weight of fish increased with the culture period regardless of treatment. Significantly $(P<0.05)$ higher condition factor was observed in rohu fed with D3 diet compared to the other diets fed fish on days-7, 14 and 21 after immunization (Table 3). There was no significant $(P>0.05)$ difference between $D 1$ and D4 diets fed rohu on days-7, 14 and 21 after immunization.

\section{Immunological Assays}

Serum lysozyme level was significantly higher in D3 diet fed rohu on days-7 and 21, and on day-14, in D3 and D2 treatments (Table 4). There was no significant difference in lysozyme level in rohu fed with $0.5 \%$ leaves and seeds enriched diets on day-14 after immunization. The highest lysozyme level $(P<0.05)$ was found on day14 after immunization in all diets, except D4. In D3 diet fed rohu, myeloperoxidase level was significantly higher compared to rohu fed with other diets throughout the experimental period. Rohu fed with D2 and D3 diets showed the highest myeloperoxidase activity on day-21 after immunization; in D1 and D4 diets, the highest levels were observed on day-7 after immunization. Significantly higher $(P<0.05)$ hemagglutination titer level was found in rohu fed with D3 diet compared to other groups. The hemagglutination titer level was maximum on day-14 after immunization regardless of feeding regimes.

Significantly higher $(P<0.05)$ nitric oxide synthase level was found in hepatopancreas of rohu fed with $0.5 \%$ seeds (D3) and $0.5 \%$ leaves (D2) enriched diets compared to rohu fed with D1 and D4 diets on day-7

Table 4. Lysozyme, myeloperoxidase and hemagglutination titer levels found in rohu fingerlings fed with enriched diets. Means $( \pm$ SE) sharing different letters in the same column are significantly $(P<0.05)$ different $(n=3)$

\begin{tabular}{|c|c|c|c|c|c|c|c|c|c|}
\hline & \multicolumn{3}{|c|}{ Serum lysozyme $(\mathrm{mg} / \mathrm{mL})$} & \multicolumn{3}{|c|}{ Myeloperoxidase (OD at $540 \mathrm{~nm}$ ) } & \multicolumn{3}{|c|}{ Hemagglutination titer } \\
\hline & 7 Days & 14 Days & 21 Days & 7 Days & 14 Days & 21 Days & 7 Days & 14 Days & 21 Days \\
\hline D1 & $1.55 \pm 0.66^{c}$ & $11.51 \pm 3.30^{\mathrm{b}}$ & $3.88 \pm 1.49^{c}$ & $2.06 \pm 0.15^{b}$ & $1.72 \pm 0.13^{b}$ & $2.03 \pm 0.06^{c}$ & $3.33 \pm 0.67^{c}$ & $21.33 \pm 5.33^{\mathrm{b}}$ & $13.33 \pm 2.67^{b}$ \\
\hline D2 & $3.35 \pm 0.80^{b}$ & $22.05 \pm 1.38^{a}$ & $8.33 \pm 0.43^{b}$ & $2.18 \pm 0.04^{b}$ & $1.87 \pm 0.10^{\mathrm{b}}$ & $2.42 \pm 0.19^{b}$ & $5.33 \pm 1.33^{b}$ & $26.67 \pm 5.33^{\mathrm{b}}$ & $13.33 \pm 2.67^{b}$ \\
\hline D3 & $4.36 \pm 1.14^{\mathrm{a}}$ & $23.44 \pm 2.54^{\mathrm{a}}$ & $14.05 \pm 1.93^{\mathrm{a}}$ & $2.35 \pm 0.13^{a}$ & $2.55 \pm 0.13^{a}$ & $2.70 \pm 0.22^{\mathrm{a}}$ & $10.67 \pm 2.67^{\mathrm{a}}$ & $53.33 \pm 10.67^{a}$ & $26.67 \pm 5.33^{\mathrm{a}}$ \\
\hline D4 & $0.73 \pm 0.56^{d}$ & $1.11 \pm 0.48^{c}$ & $1.85 \pm 0.47^{d}$ & $1.83 \pm 0.14^{c}$ & $1.06 \pm 0.23^{c}$ & $1.59 \pm 0.08^{d}$ & $2.67 \pm 0.67^{c}$ & $13.33 \pm 2.67^{c}$ & $6.67 \pm 1.33^{c}$ \\
\hline
\end{tabular}

D1: $0.25 \%$ leaves, D2: 0.5\% leaves, D3: $0.5 \%$ seeds and D4: control

The interactive effect of diets and sampling days is significant $(P<0.05)$ for serum lysozyme and non-significant $(P>0.05)$ for $M y e l o p e r o x i d a s e$ and hemagglutination titer of rohu.

Table 5. Nitric oxide synthase, thiobarbituric acid reactive substances (TBARS) and carbonyl protein levels in hepatopancreas and anterior kidney of rohu fingerlings fed with enriched diets. Means $( \pm \mathrm{SE})$ sharing different letters in the same column are significantly $(P<0.05)$ different $(n=3)$

\begin{tabular}{|c|c|c|c|c|c|c|c|c|c|}
\hline \multicolumn{10}{|c|}{ Hepatopancreas } \\
\hline & \multicolumn{3}{|c|}{ Nitric oxide Synthase ( $\mu \mathrm{mol} / \mathrm{mg}$ tissue) } & \multicolumn{3}{|c|}{ TBARS (mmol MDA/mg protein) } & \multicolumn{3}{|c|}{ Carbonyl protein (nmol/mg protein) } \\
\hline & 7 Days & 14 Days & 21 Days & 7 Days & 14 Days & 21 Days & 7 Days & 14 Days & 21 Days \\
\hline D1 & $1.61 \pm 0.06^{\mathrm{b}}$ & $3.93 \pm 0.24^{c}$ & $1.29 \pm 0.11^{c}$ & $8.15 \pm 1.25^{b}$ & $12.84 \pm 1.21^{\mathrm{b}}$ & $8.15 \pm 0.48^{b}$ & $15.59 \pm 0.69^{b}$ & $8.29 \pm 0.56^{b}$ & $11.53 \pm 1.35^{b}$ \\
\hline D2 & $5.66 \pm 0.70^{\mathrm{a}}$ & $5.89 \pm 0.27^{b}$ & $2.14 \pm 0.33^{b}$ & $7.11 \pm 1.49^{b}$ & $5.28 \pm 1.43^{c}$ & $6.91 \pm 0.52^{c}$ & $3.48 \pm 0.23^{c}$ & $5.10 \pm 1.27^{c}$ & $7.23 \pm 0.60^{c}$ \\
\hline D3 & $5.88 \pm 0.89^{a}$ & $12.40 \pm 2.53^{\mathrm{a}}$ & $3.53 \pm 0.19^{a}$ & $4.79 \pm 0.26^{c}$ & $1.43 \pm 0.53^{d}$ & $5.98 \pm 0.90^{c}$ & $2.80 \pm 0.59^{c}$ & $3.17 \pm 0.25^{d}$ & $2.69 \pm 0.36^{d}$ \\
\hline D4 & $1.47 \pm 0.16^{\mathrm{b}}$ & $2.43 \pm 0.38^{d}$ & $0.95 \pm 0.01^{\mathrm{d}}$ & $10.82 \pm 0.49^{a}$ & $25.93 \pm 1.06^{a}$ & $11.51 \pm 0.94^{a}$ & $28.37 \pm 4.41^{\mathrm{a}}$ & $22.02 \pm 3.39^{a}$ & $20.68 \pm 0.38^{a}$ \\
\hline \multicolumn{10}{|c|}{ Anterior Kidney } \\
\hline & \multicolumn{3}{|c|}{ Nitric oxide synthase ( $\mu \mathrm{mol} / \mathrm{mg}$ tissue) } & \multicolumn{3}{|c|}{ TBARS (mmol MDA/mg protein) } & \multicolumn{3}{|c|}{ Carbonyl protein (nmol/mg protein) } \\
\hline & 7 Days & 14 Days & 21 Days & 7 Days & 14 Days & 21 Days & 7 Days & 14 Days & 21 Days \\
\hline D1 & $0.72 \pm 0.06^{c}$ & $1.23 \pm 0.07^{c}$ & $0.68 \pm 0.05^{c}$ & $13.48 \pm 0.40^{b}$ & $24.99 \pm 2.02^{b}$ & $7.80 \pm 0.60^{\mathrm{b}}$ & $7.82 \pm 1.67^{b}$ & $14.83 \pm 0.67^{b}$ & $15.20 \pm 1.27^{b}$ \\
\hline D2 & $1.05 \pm 0.04^{b}$ & $1.71 \pm 0.34^{\mathrm{b}}$ & $0.96 \pm 0.02^{b}$ & $8.59 \pm 1.42^{\mathrm{c}}$ & $15.85 \pm 0.81^{\mathrm{c}}$ & $5.48 \pm 0.52^{\mathrm{c}}$ & $4.80 \pm 0.35^{c}$ & $9.65 \pm 0.30^{c}$ & $11.09 \pm 0.55^{c}$ \\
\hline D3 & $2.01 \pm 0.05^{\mathrm{a}}$ & $2.24 \pm 0.06^{a}$ & $2.19 \pm 0.08^{a}$ & $5.43 \pm 0.65^{d}$ & $10.77 \pm 1.29^{d}$ & $4.54 \pm 0.71^{\mathrm{c}}$ & $3.14 \pm 0.24^{d}$ & $6.41 \pm 0.18^{d}$ & $3.12 \pm 0.60^{d}$ \\
\hline D4 & $0.40 \pm 0.06^{d}$ & $0.90 \pm 0.04^{d}$ & $0.46 \pm 0.05^{d}$ & $22.72 \pm 1.25^{a}$ & $42.77 \pm 1.27^{a}$ & $9.28 \pm 0.84^{a}$ & $19.47 \pm 1.86^{a}$ & $22.55 \pm 0.29^{a}$ & $37.33 \pm 2.97^{a}$ \\
\hline
\end{tabular}

D1: $0.25 \%$ leaves, D2: $0.5 \%$ leaves, D3: $0.5 \%$ seeds and D4: control

The interactive effect of diets and sampling days is significant $(P<0.05)$ for nitric oxide synthase in hepatopancreas, TBARS and carbonyl protein in hepatopancreas and anterior kidney, and non-significant $(P>0.05)$ for nitric oxide synthase in anterior kidney. 
after immunization (Table 5). There was no significant difference $(P>0.05)$ between D3 and D2 diets, and between D1 and D4 diets on this day. The level increased significantly $(P<0.05)$ on day-14 after immunization and then decreased on day-21 after immunization in all diets. In anterior kidney, significantly $(P<0.05)$ higher nitric oxide synthase level was found in rohu fed with D3 diet compared to other diets fed rohu on days- 7, 14 and 21 after immunization.

\section{Oxidation of Tissue Lipid and Protein}

The study of thiobarbituric acid reactive substances (TBARS) of hepatopancreas and anterior kidney represented the tissues lipid peroxidation status (Table 5). On day-7 and day-14 after immunization, the TBARS level was significantly $(P<0.05)$ lower in hepatopancreas and anterior kidney of rohu fed with D3 diet as compared to other diets. Whereas on day-21 after immunization, significantly $(P<0.05)$ lower level of TBARS was observed in hepatopancreas and anterior kidney of rohu fed with both D2 and D3 diets as compared to other diets fed fish. In hepatopancreas and anterior kidney, carbonyl protein levels were significantly $(\mathrm{P}<0.05)$ lower in rohu fed with $\mathrm{D} 3$ diet compared to other diets throughout the experimental period, except on day-7 after immunization in hepatopancreas of fish. The highest carbonyl protein levels were recorded in hepatopancreas and anterior kidney of D4 diet fed rohu on days-7 and after immunization, respectively.

\section{Relative mRNA Expression}

In the hepatopancreas and anterior kidney, the expressions of various immune related genes were recorded on days-7, 14 and 21 after immunization. Lysozyme $\mathrm{C}$ and $\mathrm{G}$ expressions were significantly

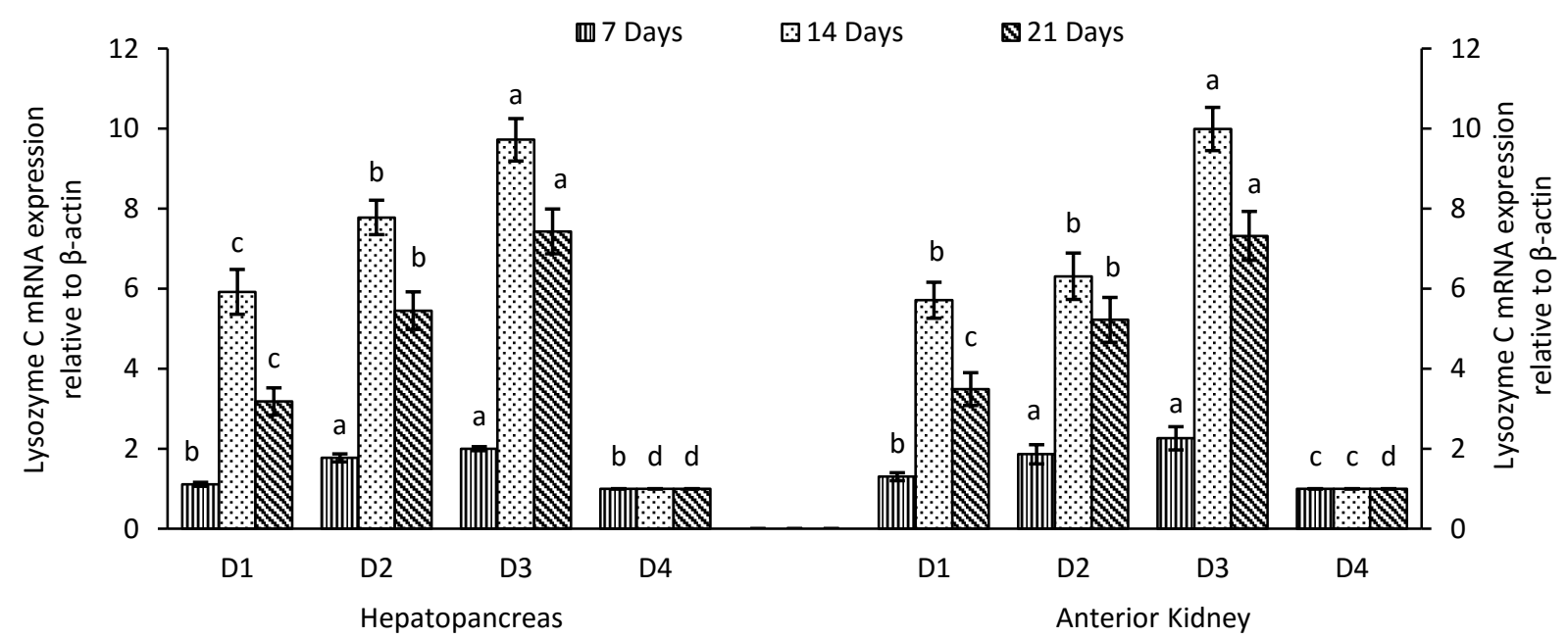

Figure 1. The relative mRNA expressions of lysozyme $C$ in hepatopancreas and anterior kidney of rohu fingerlings fed with enriched diets. Bars with different superscripts are significantly $(P<0.05)$ different $(n=3)$.

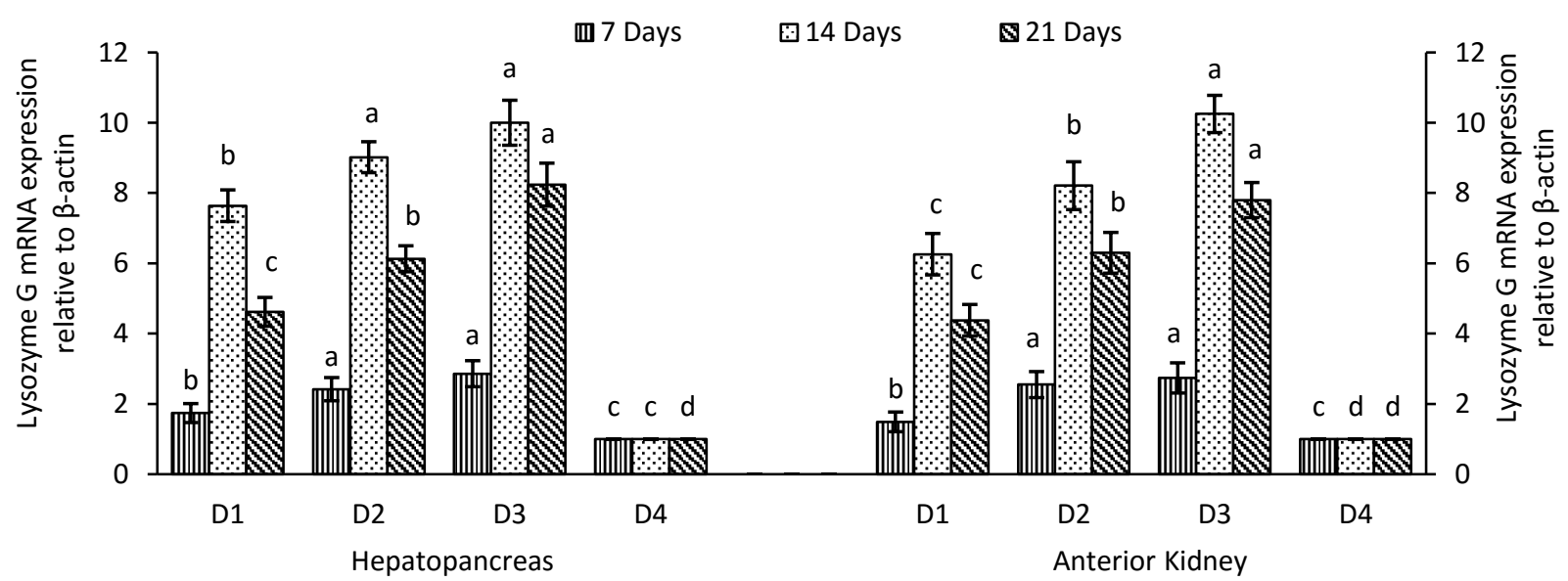

Figure 2. The relative mRNA expressions of lysozyme $G$ in hepatopancreas and anterior kidney of rohu fingerlings fed with enriched diets. Bars with different superscripts are significantly $(P<0.05)$ different $(n=3)$. 
$(P<0.05)$ higher in hepatopancreas and anterior kidney of rohu fed with enriched diets compared to the rohu fed with control diet (D4) on days-7, 14 and 21 after immunization (Figures 1 \& 2). The expression was significantly $(P<0.05)$ higher in D3 diet fed rohu compared to others. The highest expression was found on days-14 after immunization in all diets.

In hepatopancreas, TNF- $\alpha$ and IL-1 $\beta$ expressions were significantly up-regulated $(P<0.05)$ in rohu fed with leaves and seeds supplemented diets compared to the control diet (D4) fed rohu on days-7, 14 and 21 after immunization. The expression was significantly $(P<0.05)$ higher in D3 diet fed rohu on days-7 after immunization. The level of expression gradually decreased with the duration of trial (Figures 3 \& 4). In anterior kidney, the expressions of TNF- $\alpha$ and IL- $1 \beta$ genes were downregulated in rohu fed with leaves and seeds supplemented diets compared to the control diet (D4) fed rohu on days-7, 14 and 21 after immunization.

In leaves and seeds enriched diets fed rohu, significant $(P<0.05)$ down-regulation and up-regulation of IL-10 gene were recorded in hepatopancreas and anterior kidney, respectively compared to the rohu fed with D4 diet on days-7, 14 and 21 after immunization

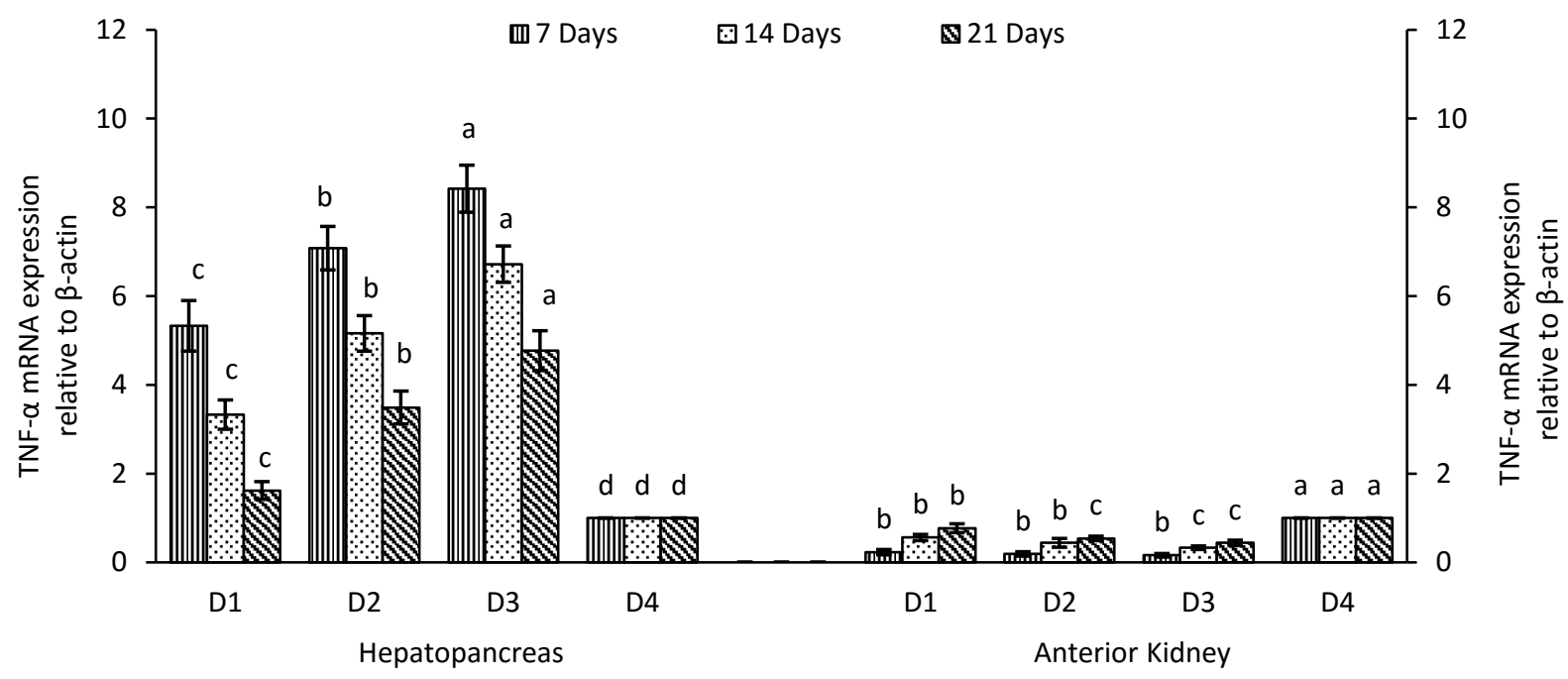

Figure 3. The relative mRNA expression level of TNF- $\alpha$ in hepatopancreas and anterior kidney of rohu fingerlings fed with enriched diets. Bars with different superscripts are significantly $(P<0.05)$ different $(n=3)$.

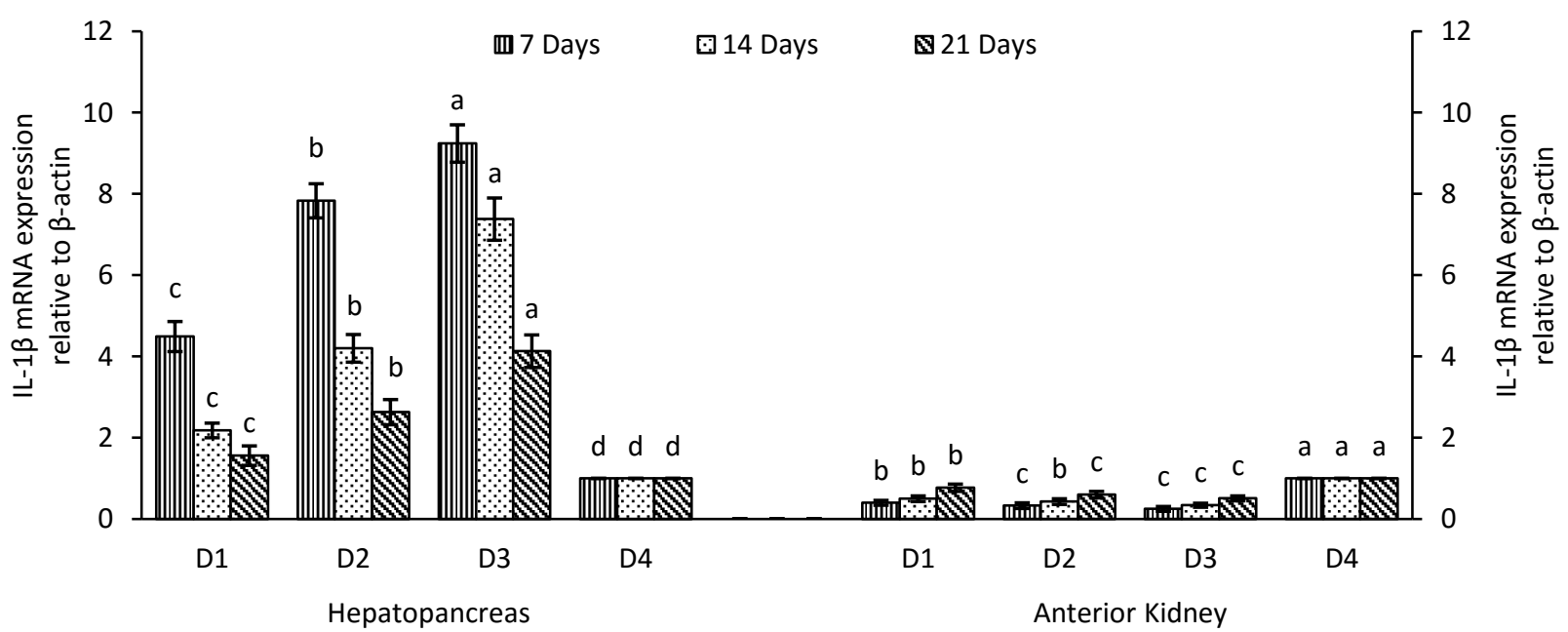

Figure 4. The relative mRNA expression of IL-1 $\beta$ in hepatopancreas and anterior kidney of rohu fingerlings fed with enriched diets. Bars with different superscripts are significantly $(P<0.05)$ different $(n=3)$. 


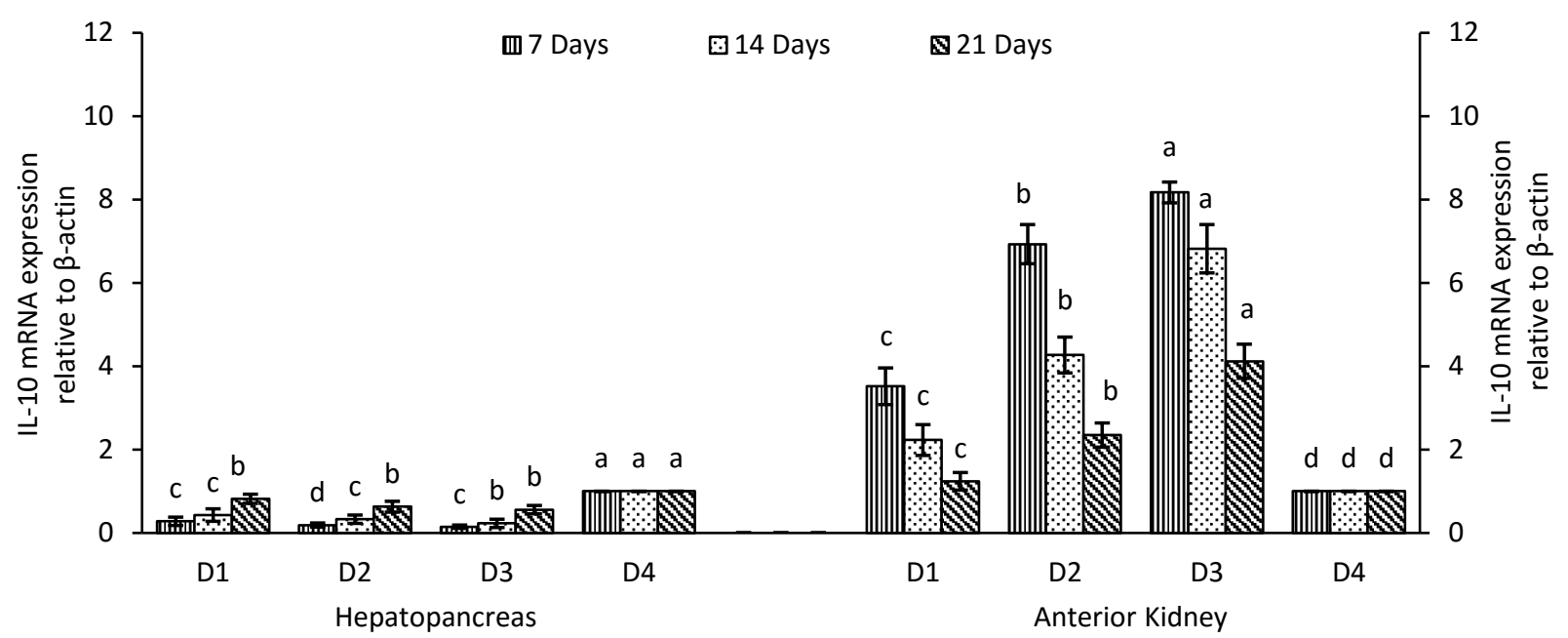

Figure 5. The relative expression of IL-10 in hepatopancreas and anterior kidney of rohu fed with enriched diets. Bars with different superscripts are significantly $(P<0.05)$ different $(n=3)$.

(Figure 5). In anterior kidney, the IL-10 expression was maximum on day-7 after immunization and then decreased in all diets.

\section{Discussion}

The enrichment of diets with leaves and seeds of A. aspera influenced the physiology and enhanced the growth of rohu fingerlings. The positive impact of both leaves and seeds at $0.5 \%$ level was found in the present study with rohu. Growth rate was higher in all enriched diets fed rohu compared to the control diet fed rohu. Earlier study reported the increased the growth in seeds and different fractions of seeds supplemented diets fed common carp (Chakrabarti et al., 2012). The enhanced growth was also observed in Nile tilapia; Oreochromis niloticus fed with Basella alba leaf extract supplemented diets (Chakraborty, Molnár, Ardó, Jeney, \& Hancz, 2015). The improved condition factor was also observed in rohu fed with $A$. aspera leaves and seeds incorporated diets. Similar improved condition factor was also observed in rainbow trout (Oncorhynchus mykiss) when fed with Coriandrum sativum extract incorporated diets (Farsani et al., 2019).

The present study showed that feeding of enriched diets improved the immune system of rohu. Lower levels of lysozyme, myeloperoxidase, nitric oxide synthase and hemagglutination titer were found in control group compared to the enriched diets fed rohu. A. aspera seeds showed better result compared to the leaves. The biochemical composition, especially presence of different amino acids and poly unsaturated fatty acids (PUFA) improved the health status of the fish. The supplementation of $0.5 \%$ leaves gave better results compared to $0.25 \%$ in rohu; the former dose may be optimum for this size group of rohu. $A$. aspera seeds containing phenolic compounds, linolenic and oleic acids and leaves containing flavonoids may influence the immune system and resulted in better performances of rohu (Chakrabarti et al., 2012; Priya, Kumar, Karthik, \& Rao, 2012). Many studies showed the influence of various herbs and their extracts in fishes, viz. ethanolic extract of grass, Cynodon dactylon (Kaleeswaran, llavenil, \& Ravikumar, 2011) in catla, Euphorbia hirta leaf extract in common carp (Pratheepa \& Sukumaran, 2014) and Azadirachta indica leaf extract in Asian seabass Lates calcarifer (Talpur \& Ikhwanuddin, 2013) enhanced lysozyme levels. Lysozyme shows bactericidal activity and thereby plays significant role in fish innate immune system. Higher myeloperoxidase activity in enriched diets fed rohu confirmed the immunostimulatory property of the ingredients. The dietary supplementation of essential oil of Citrus limon peels (Baba, Acar, Öntaş, Kesbiç, \& Yılmaz, 2016) and Nyctanthes arbortristis seeds (Kirubakaran, Subramani, \& Michael, 2016) enhanced myeloperoxidase levels in tilapia O. mossambicus. Myeloperoxidase is a specific hem containing enzyme and has significant role in the defense of organisms (Yeh \& Klesius, 2013).

Lysins, C-reactive proteins and agglutinins are important molecules and are very effective before the onset of specific immune responses. Agglutinins help in removing bacterial infections. Enhanced hemagglutination titer in enriched diets fed rohu was recorded in the present investigation. According to Sheikhzadeh, Nofouzi, Delazar, and Oushani (2011), green tea Camellia sinensis extract influenced the hemagglutination titer level in rainbow trout. The nitric oxide synthase plays an important role in inflammatory process. The higher nitric oxide synthase level was always recorded in enriched diets fed rohu. Earlier study also reported that feeding of $A$. aspera seeds incorporated diets enhanced the nitric oxide synthase level in catla (Chakrabarti, Srivastava, Verma, \& Sharma, 2014).

This study showed that feeding of rohu with enriched diets gave protection against oxidation of lipid and protein as lower levels of TBARS and carbonyl 
protein were found in the anterior kidney and hepatopancreas. Seeds provided better protection against oxidation of lipid and protein. Addition of Aloe vera in diet of GIFT-tilapia reduced lipid peroxidation (Gabriel et al., 2015). Proteins are also susceptible for reactive oxygen species attack. The accumulation of carbonyl groups is an early indication of tissue damage (Stadtman \& Oliver, 1991). The lower level of carbonyl protein in enriched diets fed rohu showed the role of plant in the prevention of oxidative stress. Reyes-Cerpa et al. (2018) found that plant extract (Saint John's wort, lemon balm, and rosemary) supplemented diet reduces the proteins carbonylation in Atlantic salmon Salmo salar.

Besides enhancing the innate immunity of rohu, this study also demonstrated that enriched diets played significant role in immune-related gene expression. The up-regulation of lysozyme $\mathrm{C}$ and lysozyme $\mathrm{G}$ genes was recorded in enriched diets fed rohu. The up-regulation of lysozyme genes also supported the increased activity of serum lysozyme in this study. Similar up-regulation of lysozyme $C$ was observed in leucine enriched diet fed rohu (Giri et al., 2015a); lysozyme G up-regulation was found in polysaccharide enriched diet fed $L$. bata (Sahoo, Parhi, Debnath, \& Prasad, 2017).

The expression of pro-inflammatory cytokine, TNF$\alpha$ is an indicator of occurrence of inflammatory process (Secombes et al., 2001). According to Low, Wadsworth, Burrells, and Secombes (2003), IL-1 $\beta$ played significant role in tissue injury and inflammation; it induced a chain of reactions through lymphocyte activation and induced release of other cytokines. The up-regulation of TNF- $\alpha$ and IL-1 $\beta$ genes were found in hepatopancreas of rohu fed with enriched diets and both these genes downregulated in anterior kidney. Co-expression of both these cytokines TNF- $\alpha$ and IL-1 $\beta$ is possible because these have similar functions of immune response initiation (Mulder, Wadsworth, \& Secombes, 2007). Earlier study showed similar results, like levan (Gupta et al., 2018) and guava leaves (Giri et al., 2015b) supplemented diets in rohu influenced proinflammatory cytokines.

In fish, IL-10s mainly inhibit the synthesis of proinflammatory cytokines (Evenhuis \& Cleveland, 2012). The down-regulation of IL-10 gene was observed in hepatopancreas and up-regulation was recorded in anterior kidney of rohu. In anterior kidney, TNF- $\alpha$ and IL$1 \beta$ genes were down-regulated and IL-10 gene was upregulated i.e. inverse relationship was observed between hepatopancreas and anterior kidney. This showed the specificity of tissue. Feeding of rohu with banana peels supplemented diets showed the similar responses of genes (Giri, Jun, Sukumaran, \& Park, 2016).

\section{Conclusions}

The present study provides information on growth promoting, immunostimulatory and stress reducing properties of $A$. aspera leaves and seeds supplemented diets. The mRNA expression of various immune related genes also supports the physiological study. A dietary inclusion of leaves/seeds at $0.5 \%$ level is recommended.

\section{Acknowledgement}

This study was supported by Department of Biotechnology (DBT), Ministry of Science \& Technology, New Delhi in the form of a research project to RC and JGS. AS is thankful to Department of Science and Technology (DST), Ministry of Science \& Technology, New Delhi for providing him INSPIRE fellowship (IF150474).

\section{References}

AOAC (Association of Official Analytical Chemists) (1990). Official methods of analysis. Washington, District of Columbia, USA, AOAC International, $673 \mathrm{pp}$.

APHA (American Public Health Association). 2012. Standard Methods for the Examination of water and waste water. APHA, Washington, District of Columbia, USA.

Baba, E., Acar, Ü., Öntaş, C., Kesbiç, O. S., \& Yılmaz, S. (2016). Evaluation of Citrus limon peels essential oil on growth performance, immune response of Mozambique tilapia Oreochromis mossambicus challenged with Edwardsiella tarda. Aquaculture, 465, 13-18. https://doi.org/10.1016/j.aquaculture.2016.08.023

Banerjee, S., Mitra, T., Purohit, G. K., Mohanty, S., \& Mohanty, B. P. (2015). Immunomodulatory effect of arsenic on cytokine and HSP gene expression in Labeo rohita fingerlings. Fish \& Shellfish Immunology, 44(1), 43-49. https://doi.org/10.1016/j.fsi.2015.01.029

Banerji, A., Chintalwar, G. J., Joshi, N. K., \& Chadha, M. S. (1971). Isolation of ecdysterone from Indian plants. Phytochemistry, 10(9), 2225-2226. https://doi.org/10.1016/S0031-9422(00)97227-3

Chakrabarti, R., \& Rao, Y. V. (2012). Achyranthes aspera enhances the immunity and antigen clearance in common carp Cyprinus carpio. Journal of Fish Diseases, 35, 389-392. https://doi.org/10.1111/j.13652761.2012.01356.x

Chakrabarti, R., \& Srivastava, P. K. (2012). Effect of dietary supplementation with Achyranthes aspera seed on larval rohu Labeo rohita challenged with Aeromonas hydrophila. Journal of Aquatic Animal Health, 24(4), 213-218.

https://doi.org/10.1080/08997659.2012.694834

Chakrabarti, R., Srivastava, P. K., Kundu, K., Khare, R. S., \& Banerjee, S. (2012). Evaluation of immunostimulatory and growth promoting effect of seed fractions of Achyranthes aspera in common carp Cyprinus carpio and identification of active constituents. Fish \& Shellfish Immunology, 32(5), 839-843. https://doi.org/10.1016/j.fsi.2012.02.006

Chakrabarti, R., Srivastava, P. K., Verma, N., \& Sharma, J. (2014). Effect of seeds of Achyranthes aspera on the immune responses and expression of some immunerelated genes in carp Catla catla. Fish \& Shellfish Immunology, 41(1), 64-69. https://doi.org/10.1016/j.fsi.2014.03.007

Chakraborty, S. B., Molnár, T., Ardó, L., Jeney, G., \& Hancz, C. (2015). Oral administration of Basella alba leaf methanol extract and genistein enhances the growth and non- 
specific immune responses of Oreochromis niloticus. Turkish Journal of Fisheries and Aquatic Sciences, 15(1), 167-173. https://doi.org/10.4194/1303-2712-v15_1_18

Dalmo, R. A., Ingebrigtsen, K., \& Bøgwald, J. (1997). Nonspecific defence mechanisms in fish, with particular reference to the reticuloendothelial system (RES). Journal of Fish Diseases, 20(4), 241-273. https://doi.org/10.1046/j.1365-2761.1997.00302.x

Defoirdt, T., Sorgeloos, P., \& Bossier, P. (2011). Alternatives to antibiotics for the control of bacterial disease in aquaculture. Current Opinion in Microbiology, 14(3), 251-258. https://doi.org/10.1016/j.mib.2011.03.004

Evenhuis, J. P., \& Cleveland, B. M. (2012). Modulation of rainbow trout (Oncorhynchus mykiss) intestinal immune gene expression following bacterial challenge. Veterinary Immunology and Immunopathology, 146(1), 8-17. https://doi.org/10.1016/j.vetimm.2012.01.008

Farsani, M. N., Hoseinifar, S. H., Rashidian, G., Farsani, H. G., Ashouri, G., \& Van Doan, H. (2019). Dietary effects of Coriandrum sativum extract on growth performance, physiological and innate immune responses and resistance of rainbow trout (Oncorhynchus mykiss) against Yersinia ruckeri. Fish \& Shellfish Immunology, 91, 233-240. https://doi.org/10.1016/j.fsi.2019.05.031

Gabriel, N. N., Qiang, J., He, J., Ma, X. Y., Kpundeh, M. D., \& Xu, P. (2015). Dietary Aloe vera supplementation on growth performance, some haemato-biochemical parameters and disease resistance against Streptococcus iniae in tilapia (GIFT). Fish \& Shellfish Immunology, 44(2), 504514. https://doi.org/10.1016/j.fsi.2015.03.002

Giri, S. S., Sen, S. S., Chi, C., Kim, H. J., Yun, S., Park, S. C., \& Sukumaran, V. (2015a). Effect of dietary leucine on the growth parameters and expression of antioxidant, immune, and inflammatory genes in the head kidney of Labeo rohita fingerlings. Veterinary immunology and immunopathology. 167(1-2), 36-43.

https://doi.org/10.1016/j.vetimm.2015.07.004

Giri, S. S., Sen, S. S., Chi, C., Kim, H. J., Yun, S., Park, S. C., \& Sukumaran, V. (2015b). Effect of guava leaves on the growth performance and cytokine gene expression of Labeo rohita and its susceptibility to Aeromonas hydrophila infection. Fish \& Shellfish Immunology, 46(2), 217-224. https://doi.org/10.1016/j.fsi.2015.05.051

Giri, S. S., Jun, J. W., Sukumaran, V., \& Park, S. C. (2016). Dietary administration of banana (Musa acuminata) peel flour affects the growth, antioxidant status, cytokine responses, and disease susceptibility of rohu, Labeo rohita. Journal of Immunology Research, 2016, 1-11. http://dx.doi.org/10.1155/2016/4086591

Gora, A. H., Sahu, N. P., Sahoo, S., Rehman, S., Dar, S. A., Ahmad, I., \& Agarwal, D. (2018). Effect of dietary Sargassum wightii and its fucoidan-rich extract on growth, immunity, disease resistance and antimicrobial peptide gene expression in Labeo rohita. International Aquatic Research, 10(2), 115-131. https://doi.org/10.1007/s40071-018-0193-6

Gupta, S. K., Sarkar, B., Bhattacharjee, S., Kumar, N., Naskar, S., \& Uppuluri, K. B. (2018). Modulation of cytokine expression by dietary levan in the pathogen aggravated rohu, Labeo rohita fingerlings. Aquaculture, 495, 496505.

https://doi.org/10.1016/j.aquaculture.2018.06.025

Halver, J. E. (1976). The nutritional requirements of cultivated warmwater and coldwater fish species. In FAO Technical Conference on Aquaculture, Kyoto (Japan), 26 May 1976.
Hariharan, V., \& Rangaswami, S. (1970). Structure of saponins $A$ and $B$ from the seeds of Achyranthes aspera. Phytochemistry, 9(2), 409-414. https://doi.org/10.1016/S0031-9422(00)85154-7

Hektoen, H., Berge, J. A., Hormazabal, V., \& Yndestad, M. (1995). Persistence of antibacterial agents in marine sediments. Aquaculture, 133(3-4), 175-184. https://doi.org/10.1016/0044-8486(94)00310-K

Huys, G., Rhodes, G., McGann, P., Denys, R., Pickup, R., Hiney, M., ... Swings, J. (2000). Characterization of oxytetracycline-resistant heterotrophic bacteria originating from hospital and freshwater fishfarm environments in England and Ireland. Systematic and Applied Microbiology, 23(4), 599-606.

https://doi.org/10.1016/S0723-2020(00)80036-3

Jian, J., \& Wu, Z. (2003). Effects of traditional Chinese medicine on nonspecific immunity and disease resistance of large yellow croaker, Pseudosciaena crocea (Richardson). Aquaculture, 218(1), 1-9. https://doi.org/10.1016/S0044-8486(02)00192-8

Kaleeswaran, B., Ilavenil, S., \& Ravikumar, S. (2011). Dietary supplementation with Cynodon dactylon (L.) enhances innate immunity and disease resistance of Indian major carp, Catla catla (Ham.). Fish \& Shellfish Immunology, 31(6), 953-962. https://doi.org/10.1016/j.fsi.2011.08.013

Kirubakaran, C. J. W., Subramani, P. A., \& Michael, R. D. (2016). Methanol extract of Nyctanthes arbor-tristis seeds enhances non-specific immune responses and protects Oreochromis mossambicus (Peters) against Aeromonas hydrophila infection. Research in Veterinary Science, 105, 243-248.

https://doi.org/10.1016/j.rvsc.2016.02.013

Lee, D.-U., Kang, Y. J., Park, M. K., Lee, Y. S., Seo, H. G., Kim, T. S., ... Chang, K. C. (2003). Effects of 13-alkyl-substituted berberine alkaloids on the expression of COX-II, TNF- $\alpha$, iNOS, and IL-12 production in LPS-stimulated macrophages. Life Sciences, 73(11), 1401-1412. https://doi.org/10.1016/S0024-3205(03)00435-1

Lenz, A.-G., Costabel, U., Shaltiel, S., \& Levine, R. L. (1989). Determination of carbonyl groups in oxidatively modified proteins by reduction with tritiated sodium borohydride. Analytical Biochemistry, 177(2), 419-425. https://doi.org/10.1016/0003-2697(89)90077-8

Livak, K. J., \& Schmittgen, T. D. (2001). Analysis of relative gene expression data using real-time quantitative PCR and the $2^{-\Delta \Delta C t}$ method. Methods, 25(4), 402-408. https://doi.org/10.1006/meth.2001.1262

Low, C., Wadsworth, S., Burrells, C., \& Secombes, C. J. (2003). Expression of immune genes in turbot (Scophthalmus maximus) fed a nucleotide-supplemented diet. Aquaculture, 221(1), 23-40. https://doi.org/10.1016/S0044-8486(03)00022-X

Mohanty, B. R., \& Sahoo, P. K. (2010). Immune responses and expression profiles of some immune-related genes in Indian major carp, Labeo rohita to Edwardsiella tarda infection. Fish \& Shellfish Immunology, 28(4), 613-621. https://doi.org/10.1016/j.fsi.2009.12.025

Montgomery, D. C. (1984). Design and analysis of experiments. New York, USA: John Wiley \& Sons.

Mulder, I. E., Wadsworth, S., \& Secombes, C. J. (2007). Cytokine expression in the intestine of rainbow trout (Oncorhynchus mykiss) during infection with Aeromonas salmonicida. Fish \& Shellfish Immunology, 23(4), 747759. https://doi.org/10.1016/j.fsi.2007.02.002 
Ohkawa, H., Ohishi, N., \& Yagi, K. (1979). Assay for lipid peroxides in animal tissues by thiobarbituric acid reaction. Analytical Biochemistry, 95(2), 351-358. https://doi.org/10.1016/0003-2697(79)90738-3

Pratheepa, V., \& Sukumaran, N. (2014). Effect of Euphorbia hirta plant leaf extract on immunostimulant response of Aeromonas hydrophila infected Cyprinus carpio. PeerJ, 2, 1-17. https://doi.org/10.7717/peerj.671

Priya, C. L., Kumar, G., Karthik, L., \& Rao, K. B. V. (2012). Phytochemical composition and in vitro antioxidant activity of Achyranthes aspera Linn (Amaranthaceae) leaf extracts. Journal of Agricultural Technology, 8(1), 143-156.

Quade, M. J., \& Roth, J. A. (1997). A rapid, direct assay to measure degranulation of bovine neutrophil primary granules. Veterinary Immunology and Immunopathology, 58(3), 239-248. https://doi.org/10.1016/S0165-2427(97)00048-2

Rao, Y. V., \& Chakrabarti, R. (2004). Enhanced anti-proteases in Labeo rohita fed with diet containing herbal ingredients. Indian Journal of Clinical Biochemistry, 19(2), 132-134. https://doi.org/10.1007/BF02894272

Rao Y. V., \& Chakrabarti, R. (2005a). Stimulation of immunity in Indian major carp Catla catla with herbal feed ingredients. Fish \& Shellfish Immunology, 18(4), 327334. https://doi.org/10.1016/j.fsi.2004.08.005

Rao, Y. V., \& Chakrabarti, R. (2005b). Dietary incorporation of Achyranthes aspera seed influences the immunity of common carp Cyprinus carpio. Indian Journal of Animal Sciences, 75(9) 1097-1102.

Rao, Y. V., Romesh, M., Singh, A., \& Chakrabarti, R. (2004). Potentiation of antibody production in Indian major carp Labeo rohita, rohu, by Achyranthes aspera as a herbal feed ingredient. Aquaculture, 238(1), 67-73. https://doi.org/10.1016/j.aquaculture.2004.04.029

Rashmi, Dayal, R., \& Nagatsu, A. (2007). Three oleanolic acid glycosides from the seeds of Achyranthes aspera. Natural Product Communications, 2, 727-730. https://doi.org/10.1177/1934578X0700200704

Vallejos-Vidal, E., Gonzalez-Bown, M. J., Morales-Reyes, J., Pérez-Stuardo, D., Vargas, D., \& Reyes-López, F. E. (2018). Effect of yeast (Xanthophyllomyces dendrorhous) and plant (Saint John's wort, lemon balm, and rosemary) extract based functional diets on antioxidant and immune status of Atlantic salmon (Salmo salar) subjected to crowding stress. Fish \& Shellfish Immunology, 74, 250-259.

https://doi.org/10.1016/j.fsi.2017.12.061

Sahoo, L., Parhi, J., Debnath, C., \& Prasad, K. P. (2017). Effect of feeding Lipopolysaccharide as an immunostimulant on immune response and immune gene expression of Labeo bata. Veterinary immunology and immunopathology, 188, 48-58.

https://doi.org/10.1016/j.vetimm.2017.04.012

Secombes, C. J., Wang, T., Hong, S., Peddie, S., Crampe, M., Laing, K. J., ... \& Zou, J. (2001). Cytokines and innate immunity of fish. Developmental \& Comparative Immunology, 25(8-9), 713-723.

https://doi.org/10.1016/\$0145-305X(01)00032-5
Sharma, J. G., Singh, M. K., \& Chakrabarti, R. (2015). Physiological responses of Catla catla larvae fed with Achyranthes aspera seed enriched diet and exposed to UV-B radiation. Indian Journal of Biochemistry and Biophysics, 52(2), 155-160.

Sharma, S. K., Vasudeva, N., \& Ali, M. (2009). A new aliphatic acid from Achyranthes aspera Linn. roots. Indian Journal of Chemistry, 48B, 1164-1169.

Sheikhzadeh, N., Nofouzi, K., Delazar, A., \& Oushani, A. K. (2011). Immunomodulatory effects of decaffeinated green tea (Camellia sinensis) on the immune system of rainbow trout (Oncorhynchus mykiss). Fish \& Shellfish Immunology, 31(6), 1268-1269. https://doi.org/10.1016/j.fsi.2011.09.010

Shendkar, C. D., Devare, S. M., Ruikar, A. D., Lavate, S. M., Jawale, R. W., \& Deshpande, N. R. (2013). Detection of amino acids from the leaves of Achyranthes aspera. Biomedrx International Journal, 1, 511-512.

Singh, M. K., Sharma, J., \& Chakrabarti, R. (2013a). Effect of UV$B$ radiation on the defence system of Labeo rohita (Actinopterygii: Cypriniformes: Cyprinidae) larvae and its modulation by seed of Devil's Horsewhip, Achyranthes aspera. Acta Ichthyologica Et Piscatoria, 43(2), 119-126. https://doi.org/10.3750/AIP2013.43.2.04

Singh, M. K., Sharma, J., \& Chakrabarti, R. (2013b). Impact of UV-B radiation on the physiology of freshwater carp Labeo rohita larvae and evaluation of UV-B protective properties of seeds of Achyranthes aspera and vitamin C. Agricultural Research, 2(2), 166-171. https://doi.org/10.1007/s40003-013-0060-z

Siwicki, A. K. (1989). Immunostimulating influence of levamisole on nonspecific immunity in carp (Cyprinus carpio). Developmental \& Comparative Immunology, 13(1), 87-91. https://doi.org/10.1016/0145305X(89)90021-9

Srivastava, P. K., \& Chakrabarti, R. (2012) Effect of dietary supplementation of Achyranthes aspera seed on the immune system of Labeo rohita fry. The Israeli Journal of Aquaculture-Bamidgeh 64, 786-792.

Stadtman, E. R., \& Oliver, C. N. (1991). Metal-catalyzed oxidation of proteins. Physiological consequences. Journal of Biological Chemistry, 266(4), 2005-2008. http://www.jbc.org/content/266/4/2005.short

Talpur, A. D., \& Ikhwanuddin, M. (2013). Azadirachta indica (neem) leaf dietary effects on the immunity response and disease resistance of Asian sea bass, Lates calcarifer challenged with Vibrio harveyi. Fish \& Shellfish Immunology, 34(1), 254-264. https://doi.org/10.1016/j.fsi.2012.11.003

Wang, W., Sun, J., Liu, C., \& Xue, Z. (2016). Application of immunostimulants in aquaculture: current knowledge and future perspectives. Aquaculture Research, 48(1), 123. https://doi.org/10.1111/are.13161

Yeh, H. Y., \& Klesius, P. H. (2013). Changes of serum myeloperoxidase and nitric oxide in the early stage of Edwardsiella ictaluri infection in channel catfish, Ictalurus punctatus (Rafinesque). Journal of Fish Diseases, 36(4), 441-446. https://doi.org/10.1111/jfd.12038 